\title{
Inhibition of lysine-specific demethylase 1 prevents proliferation and mediates cisplatin sensitivity in ovarian cancer cells
}

\author{
GENBAO SHAO $^{1 *}$, XIAOLEI WAN ${ }^{1-3^{*}}$, WENSHENG LAI ${ }^{1,3}$, CHAOYANG WU $^{2}$, JIE JIN ${ }^{1}$, \\ XIUWEN LIU ${ }^{1}$, YE WEI ${ }^{1}$, QIONG LIN ${ }^{1}$, LIUPING ZHANG ${ }^{1}$ and QIXIANG SHAO ${ }^{1}$ \\ ${ }^{1}$ Department of Basic Medicine, School of Medicine, Jiangsu University, Zhenjiang, Jiangsu 212013; \\ ${ }^{2}$ Department of Oncology, The Affiliated People's Hospital, Jiangsu University, Zhenjiang, Jiangsu 212002; \\ ${ }^{3}$ Department of Oncology, The Affiliated Jurong Hospital, Jiangsu University, Zhenjiang, Jiangsu 212400, P.R. China
}

Received March 31, 2017; Accepted January 31, 2018

DOI: $10.3892 / \mathrm{ol} .2018 .8511$

\begin{abstract}
Lysine-specific demethylase 1 (LSD1) functions as a transcriptional coregulator by modulating histone methylation and has been associated with numerous high-risk cancers. Previously, our group and others identified LSD1 as an upregulated gene in ovarian cancer, and reported that the upregulation of LSD1 was associated with poor prognosis of patients with ovarian cancer. However, the role of LSD1 in ovarian cancer requires further investigation. The present study revealed that the overexpression of LSD1 significantly promoted the proliferation of SKOV3 ovarian cancer cells, while knockdown of LSD1 markedly inhibited cell proliferation and potentiated cisplatin-induced cell apoptosis, supporting LSD1 as an oncogenic protein in ovarian cancer. Mechanistic studies have indicated that LSD1 modulates the expression of cyclin dependent kinase inhibitor 1, Survivin, B-cell lymphoma-2 (Bcl-2) and $\mathrm{Bcl}-2$-associated $\mathrm{X}$ genes, which are known regulators of cell proliferation. Furthermore, LSD1 knockdown plus cisplatin synergistically impaired cell migration via the induction of the epithelial marker E-cadherin and inhibition of the mesenchymal markers, snail family transcriptional repressor 1 and Vimentin. These data of the present study indicated LSD1 as a potential regulator of ovarian cancer cell progression and suggested an unfavorable role of LSD1 in cisplatin-based regimens.
\end{abstract}

Correspondence to: Dr Chaoyang Wu, Department of Oncology, The Affiliated People's Hospital, Jiangsu University, 8 Dianli Road, Zhenjiang, Jiangsu 212002, P.R. China

E-mail: wuchaoyang9@163.com

Dr Genbao Shao, Department of Basic Medicine, School of Medicine, Jiangsu University, 301 Xuefu Road, Zhenjiang, Jiangsu 212013, P.R. China

E-mail: gbshao07@ujs.edu.cn

${ }^{*}$ Contributed equally

Key words: lysine-specific demethylase 1, proliferation, apoptosis, cisplatin, ovarian cancer

\section{Introduction}

Ovarian cancer is the leading cause of mortality in women with gynecological malignancies (1). The standard treatment of this disease comprises surgery followed by chemotherapy; however, the prognosis is limited (2). Numerous molecular targeting therapies such as poly (adenosine 5'-diphosphate-ribose) polymerase inhibitors have been applied in the treatment of advanced cases, but the observed effects have not been satisfactory (3-5). These findings suggest that there may additional molecular targets for ovarian cancer therapy.

One of these targets may be the oncogenic protein lysine-specific demethylase 1 (LSD1). LSD1 was initially reported to specifically remove mono- and dimethyl groups from methylated histone $\mathrm{H} 3$ at lysine 4 to suppress gene expression $(6,7)$. LSD1 is frequently overexpressed in numerous cancer types, including breast (8), prostate (9), lung (10), neuroblastoma (11) and colon cancer (12). Importantly, the overexpression of LSD1 promotes cell invasion and migration in gastric cancer (13). It also contributes to the oncogenic potential of mixed lineage leukemia-AF9 leukemia stem cells and acute myeloid leukemia $(14,15)$. We and others have reported that LSD1 is upregulated in ovarian cancer tissues and cell lines (16-18); however, the role of LSD1 in ovarian cancer requires further investigation.

In the present study, the function of LSD1 on SKOV3 ovarian cancer cell proliferation and its role in therapeutic response to cisplatin were investigated. The results revealed that LSD1 promoted the proliferation and migration capacity of SKOV3 cells and enhanced their resistance to cisplatin, suggesting an unfavorable role of LSD1 in cisplatin-based regimens.

\section{Materials and methods}

Cell lines and cell culture. Human ovarian epithelial cancer cell line SKOV3 was a gift from Dr. Qixiang Shao (Jiangsu University, Zhenjiang, China). The cells were cultured as described previously (18). 293T cells were cultured in Dulbecco's modified Eagle's medium (Gibco; Thermo Fisher Scientific, Inc., Waltham, MA, USA) containing $10 \%$ fetal 
bovine serum (Gibco; Thermo Fisher Scientific, Inc.) at a temperature of $37^{\circ} \mathrm{C}$ under $5 \% \mathrm{CO}_{2}$.

Reverse transcription-quantitative polymerase chain reaction $(R T-q P C R)$. Total RNA was extracted from the LSD1-knockdown SKOV3 cells using TRIzol reagent (Invitrogen; Thermo Fisher Scientific, Inc.), according to the manufacturer's instructions, followed by treatment with DNase I (Takara Bio, Inc., Otsu, Japan). A total of $2 \mu \mathrm{g}$ RNA was reverse-transcribed using the PrimeScript RT Reagent Kit (Takara Bio, Inc.), according to the manufacturer's instructions (19). All gene transcripts were quantified via RT-qPCR using a Bio-Rad CFX96 system (Bio-Rad, Hercules, CA, USA) with SsoFast EvaGreen Supermix (Bio-Rad Laboratories, Inc., Hercules, CA, USA), according to the manufacturer's instructions. The primer sequences for each gene were as follows: Cyclin D1 forward, 5'-CAGTGCAAGGCCTGA ACCTG-3', reverse, 5'-CTTCGATCTGCTCCTGGCAGG-3'; cyclin-dependent kinase 2 (CDK2) forward, 5'-CGAGAGATC TCTCTGCTTAAG-3', reverse, 5'-GCATCCATGAATTTC

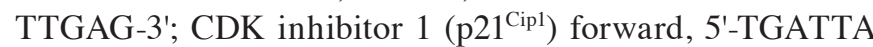
GCAGCGGAACAAG-3', reverse 5'-AAACAGTCCAGGCCA GTATG-3' and GAPDH forward, 5'-GCAAATTCCATGGCA CCGTC-3' and reverse, 5'-TCGCCCCACTTGATTTTGG-3'. The reaction parameters were as follows: an initial step at $95^{\circ} \mathrm{C}$ for $1 \mathrm{~min}$, followed by 40 cycles at $94^{\circ} \mathrm{C}$ for $10 \mathrm{sec}, 56 \sim 59^{\circ} \mathrm{C}$ for $20 \mathrm{sec}$, and $72^{\circ} \mathrm{C}$ for $20 \mathrm{sec}$. Following each PCR run, melting-curve analysis was performed for each sample to verify that a single specific product was generated. Amplicon size was confirmed by ethidium bromide staining and $2 \%$ agarose gel electrophoresis. Negative controls, composed of the PCR mix without nucleic acid, were also run with each group of samples. The abundance of each single gene was determined relative to housekeeping gene, GAPDH. Expression levels were quantified using the comparative cycle threshold $2^{-\Delta \Delta \mathrm{Cq}}$ method (20).

Western blot analysis. Total cellular proteins were isolated from the LSD1-knockdown or LSD1-overexpressing SKOV3 cells in $100 \mathrm{~mm}$ Petri dishes following a wash with ice-cold PBS and the addition of $200 \mu \mathrm{l}$ Cell and Tissue Protein Extraction Reagent (Kangchen Biotech, Shanghai, China). The protein concentration was determined using the BCA Protein Assay (Kangchen Biotech). A total of $40 \mu \mathrm{g}$ protein was separated on $8 \sim 10 \%$ SDS-PAGE gels and transferred to polyvinylidene difluoride membranes (Bio-Rad Laboratories, Inc.). The membranes were blocked with $5 \%$ milk/TBS-T (0.1\% Tween-20) for $1 \mathrm{~h}$ and immunoprobed with an antibody (diluted in 5\% BSA/TBS-T) against LSD1 (1:1,000; cat. no. 2184S; Cell Signaling Technology, Danvers, MA, USA), B-cell lymphoma-2 (Bcl-2)-associated X (Bax; 1:1,000; cat. no. ab32503; Abcam, Cambridge, MA, USA), p21 ${ }^{\text {Cip1 }}$ (1:1,000; cat. no. ab109520; Abcam), Bcl-2 (1:500; cat. no. BS1511; Bioworld Technology, Shanghai, China), Survivin (1:1,000; cat. no. BS8456; Bioworld Technology), snail family transcriptional repressor 1 (Snail; 1:500; cat. no. 9782T; Cell Signaling), Vimentin (1:500; cat. no. 9782T; Cell Signaling), E-cadherin (1:500; cat. no. 9782T; Cell Signaling), or $\alpha$-tubulin (1:1,000; cat. no. BS1699; Bioworld Technology), overnight at $4^{\circ} \mathrm{C}$. Immunodetection was achieved following incubation with a horseradish peroxidase-conjugated goat anti-rabbit or anti-mouse secondary antibody (1:10,000; BS13278 and BS12478, Bioworld Technology) in TBS-T for $1 \mathrm{~h}$ at RT. ECL reagents (Millipore, Billerica, MA, USA) were used to reveal the positive bands on the membrane (21). Images were collected with a ChemiDoc XRS system (Bio-Rad Laboratories, Inc.) and densitometry analysis was performed with an image analysis program Quantity One software v.4.6.3 (Bio-Rad Laboratories, Inc.).

Generation of stable cell lines. Lentiviruses expressing pLKO (empty vector) or pLKO-LSD1-shRNA oligos were produced as described previously (18). Shed virus was harvested at 48 and $72 \mathrm{~h}$ post-transduction. Infection of pLKO or pLKO-LSD1-shRNA lentivirus was performed by adding $1 \mathrm{ml}$ lentiviral supernatant to SKOV3 cells at $\sim 80 \%$ confluency in a $60 \mathrm{~mm}$ culture dish with $4 \mathrm{ml}$ of McCoy's 5A medium (Sigma-Aldrich; Merck KGaA, Darmstadt, Germany) supplemented with $8 \mu \mathrm{g} / \mathrm{ml}$ Polybrene (Sigma-Aldrich; Merck $\mathrm{KGaA}$ ). Stable knockdown clones were obtained under $1.5 \mu \mathrm{g} / \mathrm{ml}$ puromycin selection for 1 week.

To generate a rTet-repressor expressing (rtTA) cell line, $293 \mathrm{~T}$ cells were transfected with $2 \mu \mathrm{g}$ pLVX-Tet-On (empty vector), $1.5 \mu \mathrm{g}$ pHR'-CMV-8.2 $\Delta \mathrm{VPR}$ and $0.5 \mu \mathrm{g}$ of pHR'-CMV-VSVG (lentiviral packaging plasmids) (all kind gifts from Professor Changdeng $\mathrm{Hu}$, Purdue University, West Lafayette, IN, USA) using Lipofectamine 2000 (Thermo Fisher Scientific, Inc.). After $24 \mathrm{~h}$ transfection, the viral supernatant was harvested and used to infect SKOV3 cells. SKOV3 cells were then selected with $200 \mu \mathrm{g} / \mathrm{ml}$ G418 (Sigma-Aldrich; Merck KGaS) for 1 week. The cells that survived had been stably transfected with rtTA. The rtTA cells were infected with the lentiviral particles packaged with pLVX-Tight-Puro (control vector, obtained from Professor Changdeng Hu; Purdue University, West Lafayette, IN, USA) or pLVX-tight-puro-LSD1 produced as described previously (22). The rtTA cells were selected with $2.0 \mu \mathrm{g} / \mathrm{ml}$ puromycin for 3 days, and then maintained in the presence of $1.0 \mu \mathrm{g} / \mathrm{ml}$ puromycin for one week (22). The surviving cells were considered stable clones. The stable knockdown or overexpression clones were confirmed via western blot analysis as aforementioned.

Cell proliferation assay. Cell proliferation was assessed using Cell Counting Kit (CCK)-8 and 5-ethynyl-2'-deoxyuridene (EdU) incorporation assays. In the CCK-8 assay, the stable SKOV3 cell lines (5,000 cells/well) were plated in 96-well plates in $100 \mu \mathrm{l} \mathrm{McCoy's} \mathrm{5A} \mathrm{medium} \mathrm{per} \mathrm{well.} \mathrm{The} \mathrm{cells} \mathrm{were}$ cultured overnight at $37^{\circ} \mathrm{C}$ and then treated with 1,10 and $100 \mathrm{ng} / \mathrm{ml}$ doxycycline (Dox; Sigma-Aldrich; Merck KGaA) to induce LSD1 knockdown or overexpression for 24, 48 and $72 \mathrm{~h}$ at $37^{\circ} \mathrm{C}$. A total of $1 / 10$ volume of CCK- 8 was then added to each well and incubated for additional $2 \mathrm{~h}$ at $37^{\circ} \mathrm{C}$. The optical density was measured at $450 \mathrm{~nm}$ with a microplate reader (Bio-Rad Model 680; Bio-Rad Laboratories, Inc.). The cells from each group were added to 6 wells and the experiment was performed in triplicate.

In the EdU assay, the stable SKOV3 cell lines were plated in 24-well plates at a density of $5 \times 10^{4}$ cells/well and then treated with $100 \mathrm{ng} / \mathrm{ml}$ Dox for $48 \mathrm{~h}$ at $37^{\circ} \mathrm{C}$. The cells were incubated in serum-free Dulbecco's modified Eagle's medium 
A

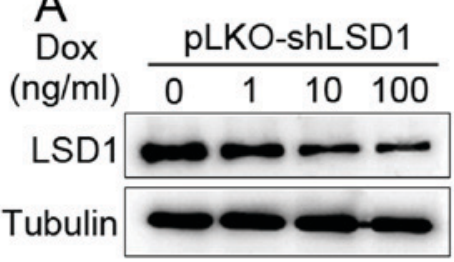

C

Dox

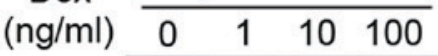

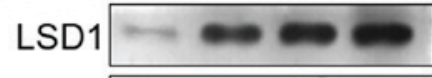

Tubulin

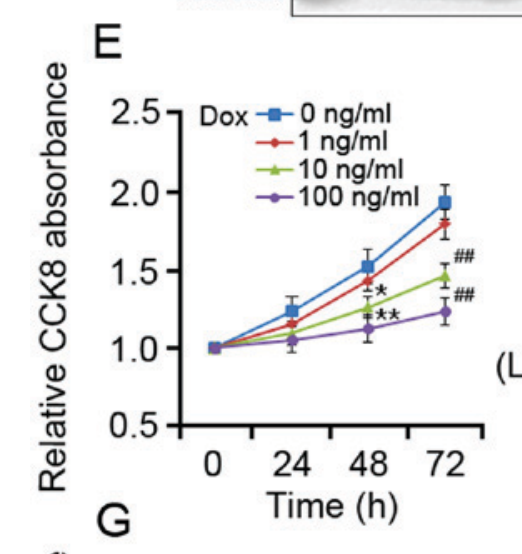

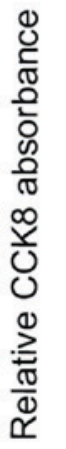

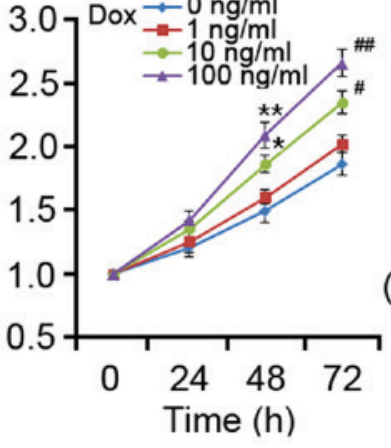

B

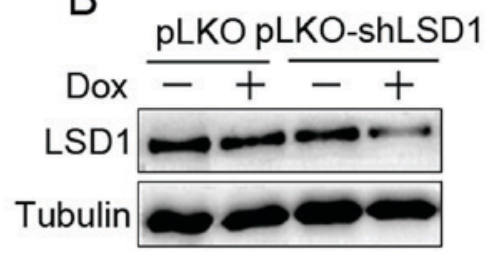

D

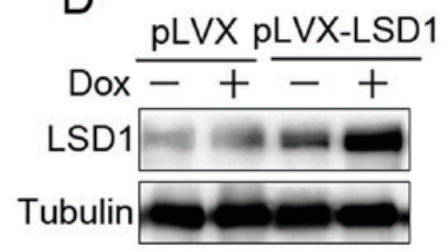

F

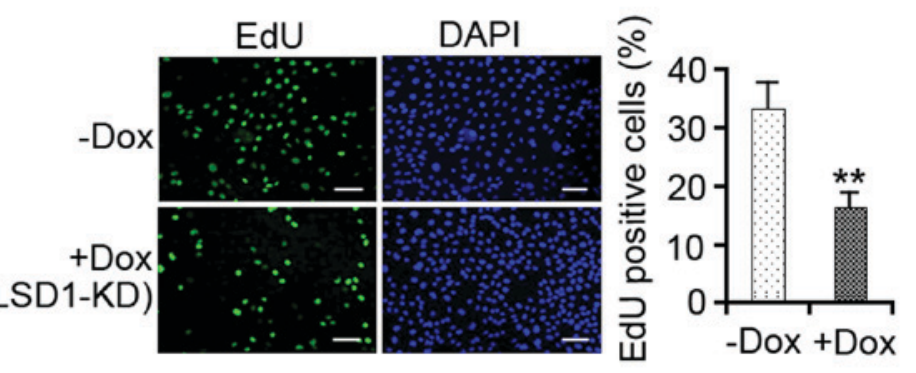

$\mathrm{H}$
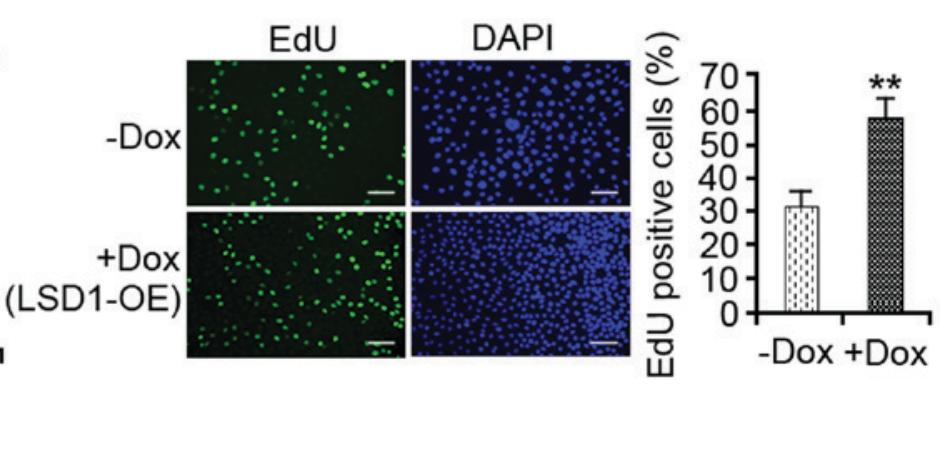

Figure 1. LSD1 is required for the proliferation of SKOV3 cells. (A) SKOV3 cells transduced with pLKO-LSD1-shRNA lentivirus were treated with different dosages of Dox for $48 \mathrm{~h}$. LSD1-KD was determined by western blotting. (B) pLKO and pLKO-LSD1-shRNA-transduced cells were treated with $100 \mathrm{ng} / \mathrm{ml}$ Dox for $48 \mathrm{~h}$ followed by western blot analysis. (C) LSD1-OE SKOV3 cells were incubated with doses of Dox for $48 \mathrm{~h}$, as indicated; the protein expression levels of LSD1 were assessed by western blotting. (D) pLVX and pLVX-LSD1-transduced cells were treated with $100 \mathrm{ng} / \mathrm{ml}$ Dox for $48 \mathrm{~h}$. Subsequently, the protein expression levels of LSD1 were detected via western blotting. (E) LSD1-KD cells were treated with doses of Dox as indicated, and cell viability was assessed using the CCK-8 assay at the indicated durations. (F) LSD1-KD cells were treated with $100 \mathrm{ng} / \mathrm{ml}$ Dox for $48 \mathrm{~h}$, and cell proliferation was assessed using the EdU incorporation assay (green). (G) LSD1-OE cells were treated with doses of Dox as indicated, and cell viability was assessed using the CCK-8 assay at the indicated durations. (H) LSD1-OE cells were treated with $100 \mathrm{ng} / \mathrm{ml}$ Dox for $48 \mathrm{~h}$, and cell proliferation was assessed using the EdU incorporation assay. Cells of the new generation were detected via EdU (green). DAPI stained nuclei (blue). Error bars represented the data as the mean \pm standard deviation (E and G, $\mathrm{n}=3 ; \mathrm{F}$ and $\mathrm{H}, \mathrm{n}=4) .{ }^{*} \mathrm{P}<0.05$ and ${ }^{* *} \mathrm{P}<0.01$, compared with the group not treated with Dox $(48 \mathrm{~h}) ;{ }^{*} \mathrm{P}<0.05$ and ${ }^{\# \#} \mathrm{P}<0.01$, compared with the group not treated with Dox (72 h). Scale bar=50 $\mu \mathrm{m}$. CCK-8, Cell Counting Kit-8; Dox, doxycycline; EdU, 5-ethynyl-2'-deoxyuridene; LSD1, lysine-specific demethylase 1; shRNA, short hairpin RNA; pLKO, empty vector; pLVX, empty vector; LSD1-KD, Dox-mediated LSD1 knockdown of cells transduced with pLKO-LSD1-shRNA; LSD1-OE, transduced with lentivirus expressing pLVX-LSD1.

(DMEM; Gibco; Thermo Fisher Scientific, Inc.) containing $50 \mathrm{mM}$ EdU for $2 \mathrm{~h}$ at $37^{\circ} \mathrm{C}$, after which the nuclei were stained with $1 \mu \mathrm{g} / \mathrm{ml}$ DAPI (cat. no. D9542, Sigma-Aldrich; Merck $\mathrm{KGaA}$ ) for $10 \mathrm{~min}$ at room temperature in the dark. The cells were imaged using an Olympus IX71 fluorescence microscope with excitation wavelengths of $460 \mathrm{~nm}$ (green) and $420 \mathrm{~nm}$ (blue). The stained cells were counted in 5 randomly selected fields (x100, magnification), and the mean value was calculated.
Cell cycle analysis. The effect of LSD1 on cell cycle phase distribution was determined by flow cytometry. The stable LSD1-knockdown SKOV3 cells $\left(1 \times 10^{6}\right.$ cells $\left./ \mathrm{ml}\right)$ were fixed in $70 \%$ ethanol for $30 \mathrm{~min}$ at $4^{\circ} \mathrm{C}$ and stained with $50 \mu \mathrm{g} / \mathrm{ml}$ propidium iodide (Sigma-Aldrich; Merck KGaA) for $30 \mathrm{~min}$ at room temperature in the dark. Subsequently, the cell cycle stages were measured with a flow cytometer (FACScan ${ }^{\circledR}, \mathrm{BD}$ Biosciences, Franklin Lakes, NJ, USA) equipped with the CellQuest software version 3.3 (BD Biosciences). 

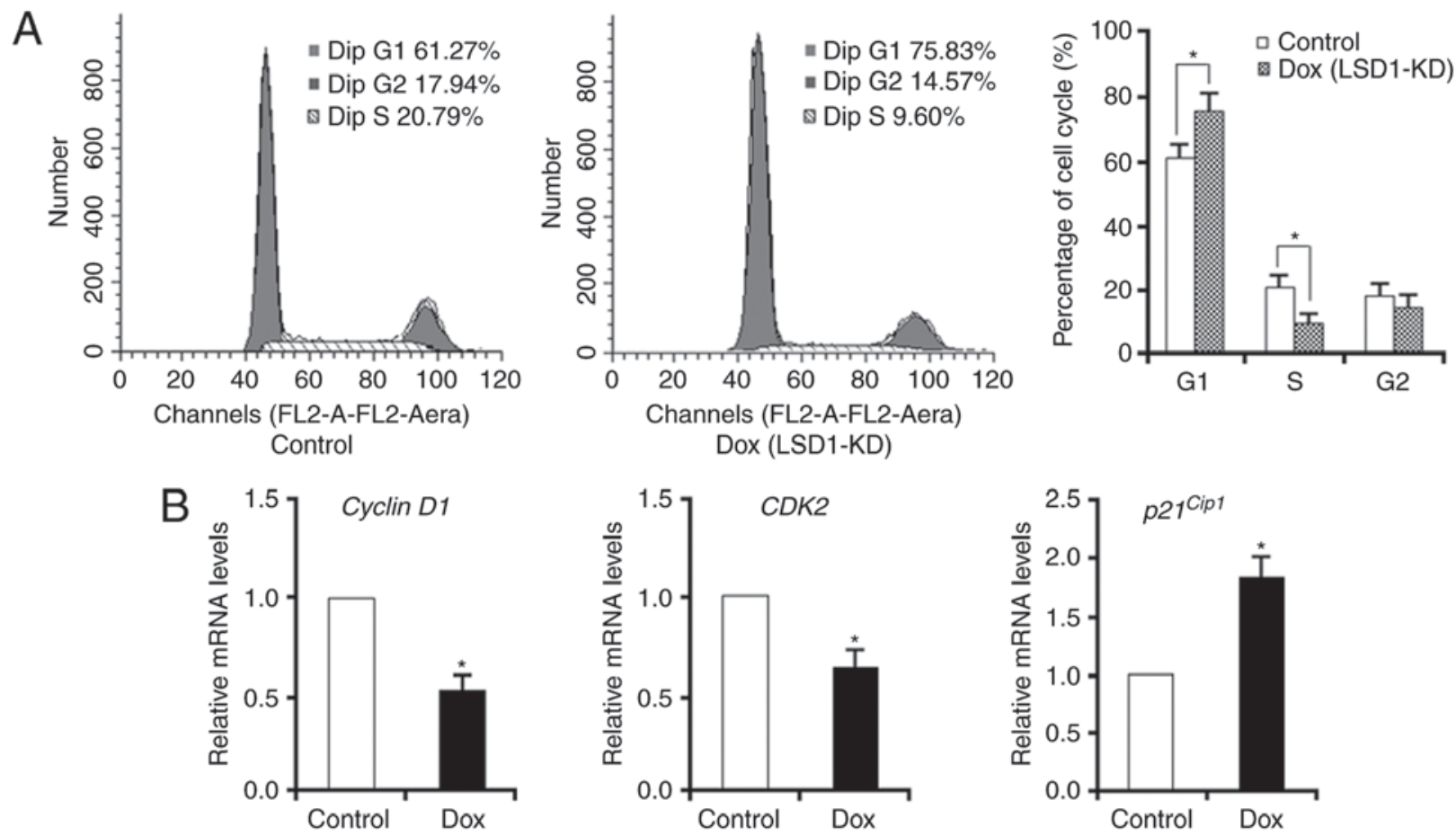

Figure 2. Knockdown of LSD1 inhibits cell-cycle progression via the G1 phase. (A) LSD1-KD cells were treated with 100 ng/ml Dox for 48 h. Flow cytometric analysis (left and middle panels) and quantitation (right panel) indicated that knockdown of LSD1 significantly induced cell cycle arrest in the G1 phase. (B) Reverse transcription-quantitative polymerase chain reaction analysis revealed a decrease in cyclin D1 and CDK2 and an increase in p21 ${ }^{\text {Cipl }}$ mRNA expression levels. Data represented as the mean \pm standard error of the mean $(n=3)$. The data were analyzed by Student's t-test $\left({ }^{*} \mathrm{P}<0.05\right)$. CDK2, cyclin-dependent kinase 2; Dox, doxycycline; LSD1, lysine-specific demethylase 1; LSD1-KD, Dox-mediated LSD1 knockdown of cells transduced with pLKO-LSD1-short hairpin RNA; p21 $1^{\text {Cip1 }}$, cyclin dependent kinase inhibitor 1.

Cell apoptosis assay. Cell apoptosis was analyzed with the fluorescein isothiocyanate (FITC) Annexin V apoptosis detection kit (Dojindo Molecular Technologies, Inc., Kumamoto, Japan). Briefly, the stable LSD1 knockdown or overexpression SKOV3 cells $\left(5 \times 10^{4}\right.$ cells/well) were treated with $100 \mathrm{ng} / \mathrm{ml}$ Dox for $24 \mathrm{~h}$ at $37^{\circ} \mathrm{C}$. After $24 \mathrm{~h}$, the cells were exposed to $5 \mu \mathrm{g} / \mathrm{ml}$ cisplatin (Sigma-Aldrich; Merck KGaA) in the presence of Dox for another $48 \mathrm{~h}$ at $37^{\circ} \mathrm{C}$. The cells were incubated in $500 \mu \mathrm{l} 1 \mathrm{X}$ Annexin $\mathrm{V}$ binding buffer at a concentration of $1 \times 10^{6}$ cells $/ \mathrm{ml}$. A total of $100 \mu 1$ of the solution was transferred to a $5-\mathrm{ml}$ culture tube and then stained with $5 \mu \mathrm{l}$ each of Annexin V-FITC and propidium iodide for $15 \mathrm{~min}$ at room temperature in the dark. Following the addition of $400 \mu \mathrm{l}$ the Annexin $\mathrm{V}$ binding buffer to each tube, the samples were analyzed using a flow cytometer (FACScan ${ }^{\circledR}$, BD Biosciences) equipped with the CellQuest software version 3.3 (BD Biosciences). All these measurements were repeated three times independently.

Cell migration assay. The migration ability of the stable LSD1 knockdown or overexpression SKOV3 cells was assessed as described previously (18). Briefly, $1.5 \times 10^{5}$ cells in $300 \mu \mathrm{l}$ of serum-free McCoy's 5A medium were placed in the upper chamber of a Transwell system (BD Biosciences). Then, $500 \mu 1$ $10 \%$ FBS-containing McCoy's 5A medium was placed in the lower chamber to act as a chemoattractant. After incubation for $24 \mathrm{~h}$ at $37^{\circ} \mathrm{C}$, the cells on the upper surface of the membrane (8- $\mu \mathrm{m}$ pore size) were removed with a wet cotton swab. The cells on the lower surface of the membrane were fixed with $4 \%$ formaldehyde for $30 \mathrm{~min}$ and stained with $0.1 \%$ crystal violet
(Sigma-Aldrich; Merck KGaA) for 15 min at room temperature. The number of the stained cells were counted under a light microscope (BX43; Olympus Corporation, Tokyo, Japan) in 5 random fields (x100, magnification), and the mean value was calculated. All experiments were performed with 3 replicates.

Statistical analysis. All values were presented as means \pm standard error of the mean. Differences in different groups were analyzed by Student's t-test or one-way analysis of variance followed by Tukey's test using SPSS 11.5 software (SPSS, Inc., Chicago, IL, USA). P<0.05 was considered to indicate a statistically significant difference.

\section{Results}

LSD1 promotes the proliferation of SKOV3 cells. To investigate the effects of LSD1 on the proliferation of SKOV3 ovarian cancer cells, stable LSD1-knockdown (LSD1-KD) clones and LSD1-overexpressing (LSD1-OE) clones were generated using SKOV3 cells in the present study. Total proteins were extracted from the stable cells treated with increasing doses of Dox for $48 \mathrm{~h}$. This time point was chosen based on previous studies (22). The results of the present study revealed that LSD1 protein expression levels were decreased in the LSD1-KD cells in a dose-dependent manner (Fig. 1A), and the reduced expression of LSD1 protein was observed in the pLKO-shLSD1 cells compared with the empty vector cells (Fig. 1B). In contrast, a dose-dependent increase in LSD1 protein expression was observed with increasing concentrations of Dox (Fig. 1C), and 
A

Cisplatin

$(\mu \mathrm{g} / \mathrm{ml})$

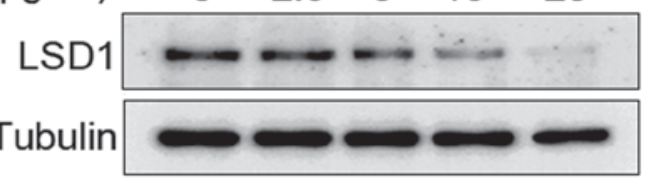

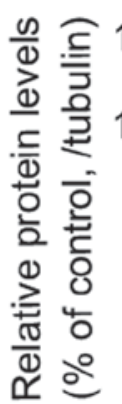

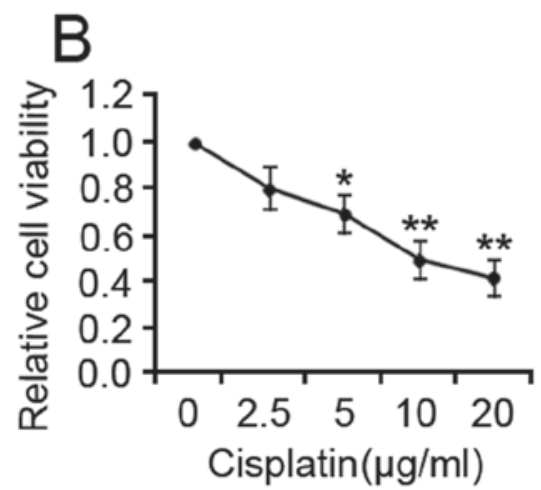

E

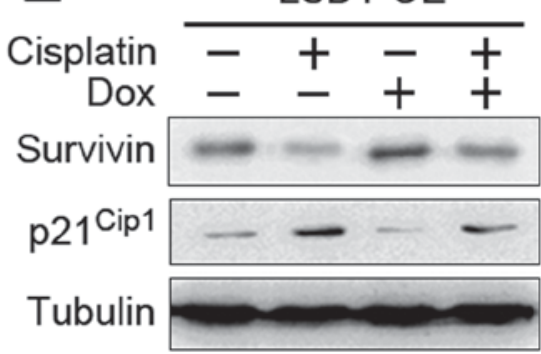

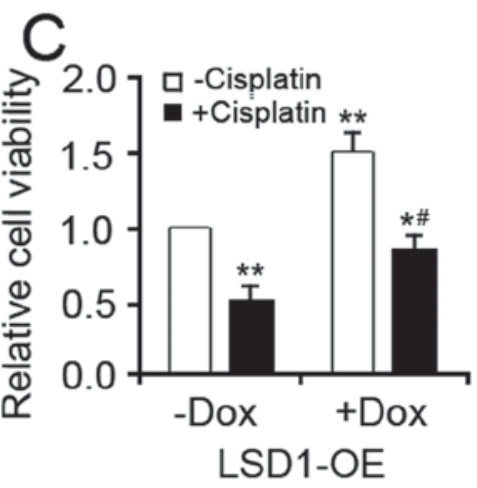

$\mathrm{D}$

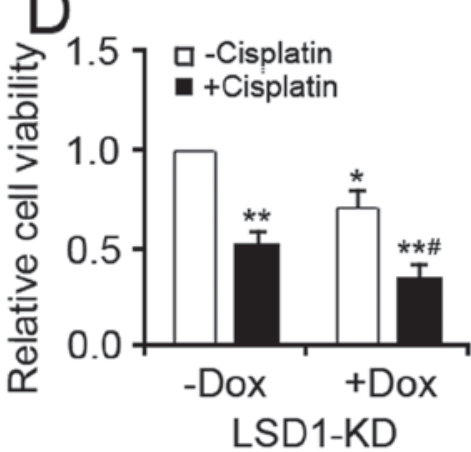

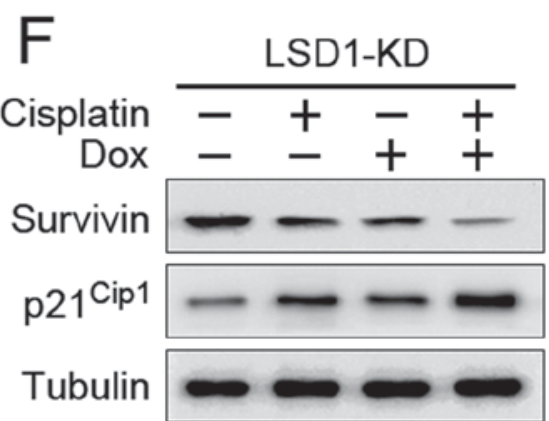

Figure 3. Effect of LSD1 on cisplatin-induced proliferation inhibition. (A) The untransduced SKOV3 cells were treated with different doses of cisplatin for $24 \mathrm{~h}$, after which LSD1 protein expression levels were detected via western blotting. (B) The unstransduced SKOV3 cells were exposed to various doses of cisplatin, as indicated, for $48 \mathrm{~h}$. Cell viability was determined via a CCK- 8 assay. Error bars represented data as the mean \pm standard error of the mean $(\mathrm{n}=3)$. ${ }^{*} \mathrm{P}<0.05$ and ${ }^{* *} \mathrm{P}<0.01$, compared with the group not treated with cisplatin. (C) LSD1-OE and (D) LSD1-KD cells were treated with either $5 \mu \mathrm{g} / \mathrm{ml}$ cisplatin, $100 \mathrm{ng} / \mathrm{ml}$ Dox, or both for $48 \mathrm{~h}$. After $48 \mathrm{~h}$, the viability of both cell lines was analyzed via the CCK- 8 assay. Error bars represented data as the mean \pm standard error of the mean $(n=3) .{ }^{*} \mathrm{P}<0.05$ and ${ }^{* *} \mathrm{P}<0.01$, compared with the group not treated with cisplatin and $\mathrm{Dox} ;{ }^{\prime} \mathrm{P}<0.05$, compared with the groups treated with cisplatin or Dox alone. After $48 \mathrm{~h}$ of cisplatin and/or Dox treatments, the protein expression levels of proliferation-associated genes were detected in the (E) LSD1-OE and (F) LSD1-KD cells via western blotting.

the expression levels of LSD1 protein were increased in the LSD1-OE cells (Fig. 1D).

To understand the effect of LSD1 expression on cell proliferation, CCK-8 and EdU assays were performed to measure the proliferative capacity of the LSD1-KD and LSD1-OE cells. The LSD1-KD cells demonstrated significantly reduced proliferative ability compared with in the control (Fig. 1E and F), whereas the LSD1-OE cells exhibited a higher proliferation rate as compared with in the control (Fig. $1 \mathrm{G}$ and $\mathrm{H}$ ).

To further determine the role of LSD1 in cell proliferation, analysis of the cell cycle was conducted via flow cytometry. Knockdown of LSD1 led to an accumulation of cells in the G1 phase $(75.8 \%)$ compared with in the control (61.3\%). In addition, there was an notable decrease in the S-phase cell fraction of LSD1-KD cells compared with the control (9.6 vs. $20.8 \%$, respectively; Fig. 2A). Furthermore, knockdown of LSD1 was associated with the significant downregulation of cyclin D1 and CDK2 and the upregulation of p21 ${ }^{\text {Cip1 }}$ (Fig. 2B). Based on these data, LSD1 silencing may inhibit cell-cycle progression via the G1 phase.

LSD1 regulation of cisplatin-induced inhibition of cell proliferation. Cisplatin resistance is a major obstacle in the treatment of ovarian carcinoma (23). To examine whether LSD1 serves a role in cisplatin resistance, the proliferation of LSD1-OE and LSD1-KD cells in response to cisplatin was analyzed. Treatment with cisplatin resulted in decreased LSD1 level in a dose-dependent manner (Fig. 3A). Cisplatin treatment also caused a dose-dependent reduction in cell proliferation (Fig. 3B). When the cells were cotreated with Dox to induce LSD1-OE, the suppressive effect of cisplatin was significantly reduced (Fig. 3C). Conversely, Dox-mediated LSD1-KD enhanced the cisplatin-induced proliferation inhibition (Fig. 3D). To further 

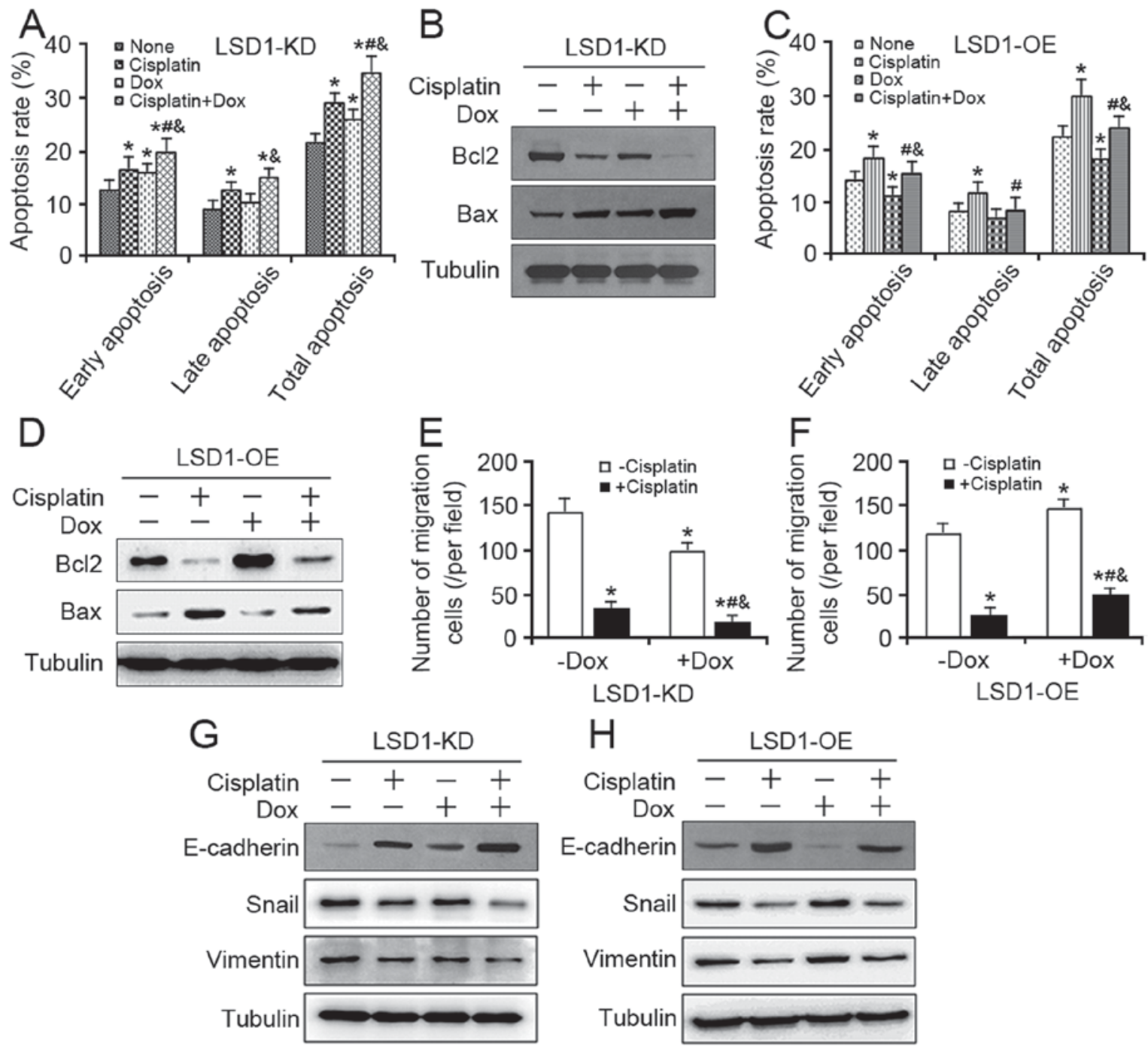

Figure 4. Effects of LSD1 on cell apoptosis and migration against cisplatin. (A) At $24 \mathrm{~h}$ after $100 \mathrm{ng} / \mathrm{ml}$ Dox induction, the LSD1-KD cells were exposed to $5 \mu \mathrm{g} / \mathrm{ml}$ cisplatin for additional $48 \mathrm{~h}$, and cell apoptosis assay was performed using the Annexin V-FITC. (B) Expression levels of Bcl2 and Bax proteins were detected in the LSD1-KD cells via western blotting. (C) At $24 \mathrm{~h}$ following induction via $100 \mathrm{ng} / \mathrm{ml}$ Dox, the LSD1-OE cells were exposed to $5 \mu \mathrm{g} / \mathrm{ml} \mathrm{cisplatin}$ for an additional $48 \mathrm{~h}$, and a cell apoptosis assay was performed using Annexin V-FITC. (D) Expression levels of Bcl2 and Bax proteins were detected in the LSD1-OE cells via western blotting. (E) After $24 \mathrm{~h}$ of induction via $100 \mathrm{ng} / \mathrm{ml}$ Dox, the trypsinized LSD1-KD and (F) LSD1-OE cells were seeded in Transwell inserts and cultured with $5 \mu \mathrm{g} / \mathrm{ml}$ cisplatin in the presence of Dox for another $24 \mathrm{~h}$, and then stained with crystal violet. (G) Following treatment with $100 \mathrm{ng} / \mathrm{ml}$ Dox for $24 \mathrm{~h}$, the LSD1-KD and (H) LSD1-OE cells were cotreated with $5 \mu \mathrm{g} / \mathrm{ml}$ cisplatin for additional $24 \mathrm{~h}$, after which the protein expression levels of epithelial-mesenchymal transition markers were detected via western blot analysis. Error bars represented data as the means \pm standard error of the mean $(\mathrm{n}=3)$. ${ }^{*} \mathrm{P}<0.05$, compared with the group not treated with cisplatin and $\mathrm{D} 0 \mathrm{x} ;{ }^{*} \mathrm{P}<0.05$, compared with the groups treated with cisplatin alone; ${ }^{\circledR} \mathrm{P}<0.05$, compared with the groups treated with Dox alone. Bc12, B-cell lymphoma-2; Bax, Bcl2-associated X; FITC, fluorescein isothiocyanate; Snail, snail family transcriptional repressor 1 .

verify the involvement of LSD1 in cisplatin-mediated proliferation inhibition, the expression of two proliferation-associated genes were analyzed. The present study reported that overexpression of LSD1 reversed the cisplatin-induced downregulation of Survivin and upregulation of $\mathrm{p}^{\mathrm{Cip1}}$ in the LSD1-OE cells compared with the cells without Dox and cisplatin (Fig. 3E), whereas knockdown of LSD1 promoted the cisplatin-induced expression of both genes in the LSD1-KD cells compared with the cells not treated with Dox and cisplatin (Fig. 3F). Collectively, these results demonstrated that LSD1 silencing may facilitate the cisplatin-induced proliferation inhibition of SKOV3 cells.

Impact of LSD1 on cell apoptosis against cisplatin. As cisplatin-induced DNA damage has been associated with the activation of both intrinsic and extrinsic apoptotic pathways $(24,25)$, whether LSD1 is associated with cisplatin-induced apoptosis was investigated in the present study. In the presence of cisplatin, the total cell apoptosis rates in the LSD1-KD group were significantly higher compared with in the corresponding control group (Fig. 4A). Additionally, the expression of proapoptotic protein Bax was notably higher in the LSD1-KD group compared with cells not treated with cisplatin and Dox, while the level of anti-apoptotic protein Bcl-2 was lower in the LSD1-KD group (Fig. 4B). Conversely, LSD1-OE significantly reduced total apoptosis and partially eliminated cisplatin-induced total apoptosis (Fig. 4C) and the expression of $\mathrm{Bcl}-2$ and $\mathrm{Bax}$ genes in the LSD1-OE group compared with the group without Dox and cisplatin (Fig. 4D). These data suggested that LSD1 inhibition may promote apoptosis by enhancing cellular responses to cisplatin. 
Effect of LSD1 on cell migration against cisplatin. We have demonstrated previously that LSD1 promotes ovarian cancer cell migration by regulating epithelial-mesenchymal transition (EMT)-associated genes (22). The potential of LSD1 in cell migration in response to cisplatin was investigated in the present study. Cell migration following exposure to cisplatin was significantly inhibited by LSD1-KD (Fig. 4E). Additionally, the inhibition of cell migration was markedly reversed by LSD1-OE (Fig. 4F). In the presence of cisplatin, SKOV3 cells exhibited an upregulation of the epithelial marker E-cadherin and a downregulation of the mesenchymal markers Snail and Vimentin. When the cells were cotreated with Dox to induce LSD1-KD, the cisplatin effects were markedly enhanced (Fig. 4G), whereas Dox-treated LSD1-OE reversed the effects of cisplatin (Fig. 4H). Collectively, these results suggested that LSD1 inhibition and cisplatin may synergistically suppress the migration of SKOV3 cells.

\section{Discussion}

LSD1 has been implicated in various types of cancers and serves an oncogenic role in cancer cell proliferation $(26,27)$. The findings of the present study support that the overexpression of LSD1 promotes cell proliferation and inhibits cell apoptosis of SKOV3 ovarian cancer cells. Additionally, the expression levels of LSD1 may be closely associated with the effects of cisplatin. When LSD1 is upregulated, the inhibitory effects of cisplatin are notably inhibited, whereas a reduction of endogenous LSD1 substantially enhances the cisplatin effects. Furthermore, cisplatin may directly downregulate LSD1 protein expression in a dose-response manner, suggesting that LSD1 is a downstream target of cisplatin. Thus, cisplatin may inhibit cell proliferation by modulating epigenetic factors, such as LSD1.

In addressing the molecular mechanisms of the LSD1 inhibitory effect on cisplatin activity, LSD1 silencing was accompanied by a reduced expression in cyclin D1, CDK2, Survivin, and Bcl-2 proteins as observed in the present study, which are known regulators of cell proliferation and survival (28). Importantly, the present study demonstrated that LSD1 knockdown plus cisplatin increased reduction in the expression of these genes. As LSD1 activates gene transcription via the demethylation of H3K9 (29), LSD1 may modulate these gene expressions via epigenetic changes to mediate its cellular function.

One of the notable findings of the present study is that cisplatin-mediated migration inhibition may be partially eliminated by exogenous expression of LSD1, whereas cisplatin plus LSD1 knockdown causes significantly decreased cell migration. This suggests that LSD1 expression is associated with the migration of ovarian cancer cells and may serve a role in the development of cisplatin resistance. Accumulating evidence demonstrates that EMT serves important roles in ovarian cancer metastasis and chemoresistance $(22,30)$. Among the multiple factors, Snail has been recognized as a central transcription factor that controls the EMT program via repressing E-cadherin expression $(31,32)$. It has also demonstrated that mesenchymal cells, which are characterized by the upregulation of Vimentin, may acquire increased migratory potential during tumor progression (32). The results of the present study revealed that LSD1 knockdown may sensitize SKOV3 cells to cisplatin by downregulating Snail and Vimentin protein expression; LSD1-overexpressing cells exhibit the protein expression profiles similar to LSD1-knockdown cells. In the future, it will be beneficial to measure whether LSD1 knockout in vivo sensitizes ovarian tumors to cisplatin.

In conclusion, the present study revealed the role of LSD1 in directing SKOV3 cell proliferation, as well as resistance to cisplatin. Overexpression of LSD1 may stimulate the expression of proliferation-associated genes, thus contributing to the proliferation of SKOV3 cells; sustained expression of LSD1 may overcome cisplatin-induced cell apoptosis. These data identify LSD1 as a regulator of SKOV3 cell potential and provide a possible therapeutic strategy against ovarian cancer.

\section{Acknowledgements}

Not applicable.

\section{Funding}

The present study was supported by grants from the National Natural Science Foundation of China (grant no. 81170573) and Clinical Medicine Science \& Technology Project of Jiangsu Province (grant no. BL2013024).

\section{Availability of data and materials}

The datasets used and/or analyzed during the current study are available from the corresponding author on reasonable request.

\section{Authors' contributions}

GS, CW and QL made substantial contributions to study conception and design, and data acquisition. XW, WL and YW performed western blotting and cell proliferation assays. XL, JJ and LZ participated in cell cycle analysis. XW and QS analyzed the data and were major contributors in writing the manuscript. All authors read and approved the final manuscript.

\section{Ethics approval and consent to participate}

The present study was endorsed by the Ethics Committee of Jiangsu University.

\section{Consent for publication}

Not applicable.

\section{Competing interests}

The authors declare that they have no competing interests.

\section{References}

1. Ali AY, Farrand L, Kim JY, Byun S, Suh JY, Lee HJ and Tsang BK: Molecular determinants of ovarian cancer chemoresistance: New insights into an old conundrum. Ann N Y Acad Sci 1271: 58-67, 2012 
2. Vaughan S, Coward JI, Bast RC Jr, Berchuck A, Berek JS, Brenton JD, Coukos G, Crum CC, Drapkin R, Etemadmoghadam D, et al: Rethinking ovarian cancer: Recommendations for improving outcomes. Nat Rev Cancer 11: 719-725, 2011.

3. Behbakht K, Sill MW, Darcy KM, Rubin SC, Mannel RS, Waggoner S, Schilder RJ, Cai KQ, Godwin AK and Alpaugh RK Phase II trial of the mTOR inhibitor, temsirolimus and evaluation of circulating tumor cells and tumor biomarkers in persistent and recurrent epithelial ovarian and primary peritoneal malignancies: A Gynecologic Oncology Group study. Gynecol Oncol 123: 19-26, 2011.

4. Ledermann J, Harter P, Gourley C, Friedlander M, Vergote I, Rustin G, Scott CL, Meier W, Shapira-Frommer R, Safra T, et al: Olaparib maintenance therapy in patients with platinum-sensitive relapsed serous ovarian cancer: A preplanned retrospective analysis of outcomes by BRCA status in a randomised phase 2 trial. Lancet Oncol 15: 852-861, 2014.

5. Matulonis UA, Berlin S, Ivy P, Tyburski K, Krasner C, Zarwan C, Berkenblit A, Campos S, Horowitz N, Cannistra SA, et al: Cediranib, an oral inhibitor of vascular endothelial growth factor receptor kinases, is an active drug in recurrent epithelial ovarian, fallopian tube, and peritoneal cancer. J Clin Oncol 27: 5601-5606, 2009.

6. Lan F, Nottke AC and Shi Y: Mechanisms involved in the regulation of histone lysine demethylases. Curr Opin Cell Biol 20: 316-325, 2008

7. Metzger E, Wissmann M, Yin N, Müller JM, Schneider R, Peters AH, GüntherT, Buettner R and Schüle R: LSD1 demethylates repressive histone marks to promote androgen-receptor-dependent transcription. Nature 437: 436-439, 2005.

8. Lim S, Janzer A, Becker A, Zimmer A, Schüle R, Buettner R and Kirfel J: Lysine-specific demethylase 1 (LSD1) is highly expressed in ER-negative breast cancers and a biomarker predicting aggressive biology. Carcinogenesis 31: 512-520, 2010

9. Wu CY, Hsieh CY, Huang KE, Chang C and Kang HY: Cryptotanshinone down-regulates androgen receptor signaling by modulating lysine-specific demethylase 1 function. Int J Cancer 131: 1423-1434, 2012

10. Hayami S, Kelly JD, Cho HS, Yoshimatsu M, Unoki M, Tsunoda T, Field HI, Neal DE, Yamaue H, Ponder BA, et al: Overexpression of LSD1 contributes to human carcinogenesis through chromatin regulation in various cancers. Int J Cancer 128: 574-586, 2011.

11. Schulte JH, Lim S, Schramm A, Friedrichs N, Koster J, Versteeg R, Ora I, Pajtler K, Klein-Hitpass L, Kuhfittig-Kulle S, et al: Lysine-specific demethylase 1 is strongly expressed in poorly differentiated neuroblastoma: Implications for therapy. Cancer Res 69: 2065-2071, 2009.

12. Huang Y, Greene E, Murray Stewart T, Goodwin AC, Baylin SB, Woster PM and Casero RA Jr: Inhibition of lysine-specific demethylase 1 by polyamine analogues results in reexpression of aberrantly silenced genes. Proc Natl Acad Sci USA 104: 8023-8028, 2007.

13. Zheng YC, Duan YC, Ma JL, Xu RM, Zi X, Lv WL, Wang MM, Ye XW, Zhu S, Mobley D, et al: Triazole-dithiocarbamate based selective lysine specific demethylase 1 (LSD1) inactivators inhibit gastric cancer cell growth, invasion, and migration. J Med Chem 56: 8543-8560, 2013.

14. Harris WJ, Huang X, Lynch JT, Spencer GJ, Hitchin JR, Li Y, Ciceri F, Blaser JG, Greystoke BF, Jordan AM, et al: The histone demethylase KDM1A sustains the oncogenic potential of MLL-AF9 leukemia stem cells. Cancer Cell 21: 473-487, 2012.

15. Schenk T, Chen WC, Göllner S, Howell L, Jin L, Hebestreit K, Klein HU, Popescu AC, Burnett A, Mills K, et al: Inhibition of the LSD1 (KDM1A) demethylase reactivates the all-trans-retinoic acid differentiation pathway in acute myeloid leukemia. Nat Med 18: 605-611, 2012.

16. Chen C, Ge J, Lu Q, Ping G, Yang C and Fang X: Expression of Lysine-specific demethylase 1 in human epithelial ovarian cancer. J Ovarian Res 8: 28, 2015
17. Konovalov S and Garcia-Bassets I: Analysis of the levels of lysine-specific demethylase 1 (LSD1) mRNA in human ovarian tumors and the effects of chemical LSD1 inhibitors in ovarian cancer cell lines. J Ovarian Res 6: 75, 2013.

18. Shao G, Wang J, Li Y, Liu X, Xie X, Wan X, Yan M, Jin J, Lin Q, Zhu $\mathrm{H}$, et al: Lysine-specific demethylase 1 mediates epidermal growth factor signaling to promote cell migration in ovarian cancer cells. Sci Rep 5: 15344, 2015.

19. Shao GB, Wang J, Zhang LP, Wu CY, Jin J, Sang JR, Lu HY, Gong AH, Du FY and Peng WX: Aging alters histone H3 lysine 4 methylation in mouse germinal vesicle stage oocytes. Reprod Fertil Dev 27: 419-426, 2015

20. Livak KJ and Schmittgen TD: Analysis of relative gene expression data using real-time quantitative PCR and the 2(-Delta Delta C(T)) method. Methods 25: 402-408, 2001.

21. Zhang L, Wang J, Pan Y, Jin J, Sang J, Huang P and Shao G: Expression of histone $\mathrm{H} 3$ lysine 4 methylation and its demethylases in the developing mouse testis. Cell Tissue Res 358: 875-883, 2014.

22. Li Y, Wan X, Wei Y, Liu X, Lai W, Zhang L, Jin J, Wu C, Shao Q, Shao G and Lin Q: LSD1-mediated epigenetic modification contributes to ovarian cancer cell migration and invasion. Oncol Rep 35: 3586-3592, 2016

23. Davis A, Tinker AV and Friedlander M: 'Platinum resistant' ovarian cancer: What is it, who to treat and how to measure benefit. Gynecol Oncol 133: 624-631, 2014.

24. Hayakawa J, Ohmichi M, Kurachi H, Ikegami H, Kimura A, Matsuoka T, Jikihara H, Mercola D and Murata Y: Inhibition of extracellular signal-regulated protein kinase or c-Jun N-terminal protein kinase cascade, differentially activated by cisplatin, sensitizes human ovarian cancer cell line. J Biol Chem 274 31648-31654, 1999.

25. Persons DL, Yazlovitskaya EM, Cui W and Pelling JC: Cisplatin-induced activation of mitogen-activated protein kinases in ovarian carcinoma cells: Inhibition of extracellular signal-regulated kinase activity increases sensitivity to cisplatin. Clin Cancer Res 5: 1007-1014, 1999.

26. Ding J, Zhang ZM, Xia Y, Liao GQ, Pan Y, Liu S, Zhang Y and Yan ZS: LSD1-mediated epigenetic modification contributes to proliferation and metastasis of colon cancer. Br J Cancer 109: 994-1003, 2013.

27. Wang GG, Allis CD and Chi P: Chromatin remodeling and cancer, Part I: Covalent histone modifications. Trends Mol Med 13: 363-372, 2007

28. Li M, Lewis B, Capuco AV, Laucirica R and Furth PA: WAP-TAg transgenic mice and the study of dysregulated cell survival, proliferation, and mutation during breast carcinogenesis. Oncogene 19: 1010-1019, 2000.

29. El Mansouri FE, Nebbaki SS,Kapoor M, AfifH,Martel-Pelletier J, Pelletier JP, Benderdour M and Fahmi H: Lysine-specific demethylase 1-mediated demethylation of histone $\mathrm{H} 3$ lysine 9 contributes to interleukin $1 \beta$-induced microsomal prostaglandin E synthase 1 expression in human osteoarthritic chondrocytes. Arthritis Res Ther 16: R113, 2014.

30. Vergara D, Merlot B, Lucot JP, Collinet P, Vinatier D, Fournier I and Salzet M: Epithelial-mesenchymal transition in ovarian cancer. Cancer Lett 291: 59-66, 2010.

31. Lin T, Ponn A, Hu X, Law BK and Lu J: Requirement of the histone demethylase LSD1 in Snail-mediated transcriptional repression during epithelial-mesenchymal transition. Oncogene 29: 4896-4904, 2010.

32. Lin Y, Wu Y, Li J, Dong C, Ye X, Chi YI, Evers BM and Zhou BP: The SNAG domain of Snaill functions as a molecular hook for recruiting lysine-specific demethylase 1. EMBO J 29: 1803-1816, 2010 .

This work is licensed under a Creative Commons Attribution-NonCommercial-NoDerivatives 4.0 International (CC BY-NC-ND 4.0) License. 